\title{
Effects of different hydration treatments on technological, physical, nutritional, and bioactive parameters of lentils
}

\author{
Efectos de diferentes tratamientos de hidratación sobre los parámetros \\ tecnológicos, físicos, nutricionales y bioactivos de las lentejas
}

\begin{abstract}
Regular lentil consumption may improve health and prevent certain chronic diseases. Lentils have high antioxidant activity and contain proteins, essential amino acids, fiber, minerals, and bioactive compounds. However, few studies have investigated the physicochemical characteristics of lentils when subjected to various soaking and cooking methods. We aimed to evaluate the effects of different hydration and cooking practices on the hydration coefficient, cooking time, primary metabolism compounds (lipids, proteins, fibers, carbohydrates), energy value, soluble protein, color and texture characteristics, amino acid and mineral profiles, bioactive compounds, antioxidant activity, and antinutritional factors (phytates and tannins) in lentils. Hydration water was preheated to initial temperatures of $25^{\circ} \mathrm{C}$ or $90^{\circ} \mathrm{C}$. Lentils pre-hydrated with water at $90^{\circ} \mathrm{C}$ needed less cooking time, obtained greater softness, and had less decreases in amino acids, minerals, bioactive compounds, and antioxidant activity.

Keywords: Health; Hydration coefficient; Lentils; Nutritional value; Temperature.
\end{abstract}

\section{RESUMEN}

El consumo regular de lentejas puede mejorar la salud y prevenir ciertas enfermedades crónicas. Las lentejas tienen una alta actividad antioxidante y contienen proteínas, aminoácidos esenciales, fibra, minerales y compuestos bioactivos. Sin embargo, pocos estudios han investigado las características fisicoquímicas de las lentejas sometidas a varios métodos de remojo y cocción. El objetivo de este estudio fue evaluar los efectos de diferentes procesos de cocción e hidratación sobre el coeficiente de hidratación, el tiempo de cocción, los metabolitos primarios (lípidos, proteínas, fibras, carbohidratos), el valor energético, la proteína soluble, color y textura, los perfiles de aminoácidos y minerales, los compuestos bioactivos, la actividad antioxidante y los factores antinutricionales (fitatos y taninos) en la lenteja. El agua de hidratación se precalentó a temperaturas iniciales de $25^{\circ} \mathrm{Co} 90^{\circ} \mathrm{C}$. Las lentejas prehidratadas con agua a $90^{\circ} \mathrm{C}$ necesitaban menos tiempo de cocción y obtuvieron una mayor suavidad, disminuyendo también la
Guilherme Bragança ${ }^{1,2^{*}}$, Bianca Ávila ${ }^{1}$, Reni Rockenbach ${ }^{2}$, Magda Santos ${ }^{3}$, Gabriela Alves ${ }^{4}$, Mônica de los Santos², Vera Bortolini', Jander Monks ${ }^{4}$, William Peres ${ }^{1}$, Moacir Elias ${ }^{1}$.

1. Federal University of Pelotas, Post-graduate Program in Food Science and Technology (PPGCTA), Capão do Leão-RS-Brazil. 2. Campaign Region University Center, Bagé-RS-Brasil. 3. Federal Institute South Rio Grandense (IFSUL Jaguarão), Campus Jaguarão, Jaguarão-RS-Brasil.

4. Federal Institute South Rio Grandense (IFSUL Pelotas), Campus Pelotas, Pelotas-RS-Brazil.

Corresponding author: Guilherme Bragança. Department of Agroindustrial Science and Technology, Federal University of Pelotas, 96160-000, Pelotas-RS-Brazil.

E-mail: guilhermebraganca@urcamp.edu.br

pérdida de aminoácidos, minerales, compuestos bioactivos y actividad antioxidante.

Palabras clave: Coeficiente de hidratación; Lentejas; Salud; Temperatura; Valor nutricional.

\section{INTRODUCTION}

Lentils are members of the Fabaceae family. They have significant nutritional value by being a source of proteins ${ }^{1}$, essential amino acids, and considerable levels of carbohydrates, fiber, lipids, and minerals. Daily intake of lentils is associated with improved health and prevention of certain chronic diseases, including diabetes mellitus and cardiovascular diseases ${ }^{2}$, especially because of its antioxidant activity ${ }^{3}$. 
Legumes are widely used for human consumption in different regions of the planet, mainly for their nutritional importance ${ }^{4}$. The members of the Fabaceae family are, in general, widely appreciated and considered as staple foods in the nutrition of less economically favored societies, because of their energy and protein capacity ${ }^{5}$. It is known, however, that they also have antinutritional factors such as tannins, phytates, proteolytic enzyme inhibitors, lectin ${ }^{6}$ and trypsin inhibitors?.

One of the most produced fabaceous grains in the world is Lens culinaris L., known as lentils, cultivated and consumed beginning about 9,500 to 13,000 years ago ${ }^{8}$. Lentils are highly consumed by children ${ }^{9}$ and as a protein source for non-meat eating consumers ${ }^{1}$, as it is a food source with high nutritional value. In addition to its nutritional value, lentils have an important phenolic composition, which has been associated with a reduction in the incidence of chronic degenerative diseases such as diabetes, cardiovascular diseases and cancers, being considered one of the best foods to have in the diet $^{10}$.

However, although it is an important nutritional source, consumer preference for Fabaceae consumption is influenced by the physics and technological parameters like color of the raw grains and their texture following cooking ${ }^{11}$.

In the global agricultural scenario, lentils are configured as one of the leguminous plants of greatest interest because they have significant representativeness both for human nutrition and for animal feed, also being an important economic agent in many countries. As in the American continent, lentils are an important source of economic maintenance for countries in Asia and Africa ${ }^{12}$, with Argentina and Canada being important exporters to countries in Latin America, which relates to large financial amounts.

Although lentils are one of the most consumed grains in the eastern world, in the West, especially in South America, lentil consumption is still limited due also to lack of information on preparation and cooking procedures that guarantee maintenance of their nutritional qualities ${ }^{13}$. It is known that cooking heat may alter availability of the amino ac

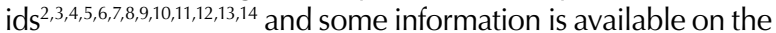
anti-nutritional factors such as tannins and phytates ${ }^{4}$. However, little information is available on the chemical composition of lentils subjected to hydrothermal processing ${ }^{15}$, such as soaking in water at different temperatures before cooking.

Considering the economic and nutritional value of lentils, we aimed to study how different ways of processing and cooking lentils may affect nutritional properties. We evaluated the effects of presoaking on the hydration coefficient of lentils, time required for cooking, proximate composition, energy value, soluble proteins, colorimetric and texturometer characteristics, amino acid and mineral profiles, bioactive compounds, antioxidant activity, and anti-nutritional factors. This manuscript is an important source of information for lentil growers and consumers, especially those who wish to reduce their intake of meat and increase their intake of grain-derived proteins.

\section{MATERIALS AND METHODS}

Lentils were stored at $15 \pm 1^{\circ} \mathrm{C}$ in a biological oxygendemand (BOD) incubator until analyzed. As all analyses were performed after 15 days, samples were stored in the BOD at a controlled temperature. This was important because raw lentils exposed to temperature variations could undergo great stress, bringing distorted results, especially for secondary metabolism compounds, such as phenolic derivatives and antioxidant activity. For cooked grains, storage in the BOD was necessary to avoid contamination and/or proliferation of microorganisms, and also to keep them in the same conditions, preventing one more factor from interfering with the results. Tests were performed at the Post-harvest, Industrialization, and Grains Quality Laboratory of the Federal University of Pelotas in Capão do Leão, Brazil, and at the Chemical Laboratory of the Sul-Rio-Grandense Federal Institute, Pelotas, Brazil.

Physicochemical, nutritional, and technological parameters were measured for raw lentils, cooked lentils without hydration, and after four different hydration treatments described below. Lentils were hydrated in distilled water $(1: 4, \mathrm{v} / \mathrm{w})$ at an initial temperature of $25 \pm 2{ }^{\circ} \mathrm{C}$ for $4 \mathrm{~h}$ and divided into two portions. The hydration water of the first portion was removed and replaced with an equal volume of distilled water for cooking purposes (LSA25). For the second portion, the hydration water was retained and used for cooking purposes (LCA25). A second group was soaked in distilled water $(1: 4, \mathrm{v} / \mathrm{w})$ at an initial temperature of $90 \pm 2{ }^{\circ} \mathrm{C}$ for $3 \mathrm{~h}$ and divided into two portions. The first portion was cooked after the soaking water was replaced with an equal volume of distilled water (LSA90). The second portion was cooked in the same hydration water (LCA90).

Lentils were pressure cooked at $203 \mathrm{kPa}$ and $116^{\circ} \mathrm{C}$. Cook time was determined by the tactile method proposed by Vindiolaet $\mathrm{al}^{16}$, where cooking is considered complete when an amount $\geq 90 \%$ of the grains is defined as softened after tactile pressure with the thumb and forefinger. Pre-hydrated lentils cooked in $46.67 \%$ less time than non-hydrated lentils. It was decided to keep the times different based on the fact that if the hydrated lentil remained cooking for the same amount of time they would disintegrate. This fact would also bring unreliable texture results and would produce destruction of countless lentil compounds, creating results that are not representative of reality. The cooking time of unhydrated lentils was not reduced, due to the fact that the grain was not completely cooked. Although we did not conduct a sensory evaluation, we considered fully cooked as an acceptable standard, thinking that the consumer does not cook until the grain disintegrates, but, on the other hand, does not consume it rigidly. All analyses except texturometer measurements were conducted on both raw and cooked lentils. Texturometer measurement was performed on cooked lentils only because lentils are not consumed raw and texture is an important technological 
parameter for indicating palatability, that is, cooking point for consumption. Another factor that makes clear that lentil shouldn't be consumed without cooking is the presence of antinutritional factors such as phytates and tannins, which, when ingested, reduce the absorption of minerals and proteins, with these factors reduced with increasing temperature.

\section{Hydration curves}

Hydration curves were plotted to establish the times at which the lentil was fully hydrated using water at initial water temperatures of $25 \pm 2{ }^{\circ} \mathrm{C}$ or $90 \pm 2{ }^{\circ} \mathrm{C}$.

Hydrothermal behavior of the raw lentils was determined using a method developed at the Post-harvest, Industrialization and Grains Quality Laboratory of the Federal University of Pelotas, as described below. For the soaking treatments, the samples were taken from the water and placed in a capsule in the centrifuge, which contained $3 \mathrm{~cm}$ of cotton in the bottom every 15 minutes. Samples were centrifuged for $1 \mathrm{~min}$ at $1000 \mathrm{rpm}$, after which samples were weighed. This procedure was repeated until all the samples obtained constant weight. The moisture percentage $(\% \mathrm{~m} / \mathrm{m})$ of each sample was measured based on the time to total hydration in a climate-controlled environment at $25{ }^{\circ} \mathrm{C}$ with $65 \%$ relative humidity. Hydration curves were plotted by using polynomial regression. Hydration coefficients $(\mathrm{HC})$ were calculated for the duration of time required for maximum hydration ${ }^{17}$ using the formula 1 below, where $\mathrm{PGH}$ represents lentil weight before hydration and $\mathrm{PAH}$ represents lentil weight after hydration.

$\mathrm{HC}=\frac{\mathrm{PGH}}{\mathrm{PAH}} \times 100$

The determination coefficient (R2) was calculated to determine the best fitting regression line ${ }^{18}$.

The objective was not to perform mathematical modeling of the water absorption kinetics on the part of the lentil, but rather to show which hydration type would be most efficient in reducing cooking time and ensure the maintenance of the technological, physical, nutritional and bioactive quality of the lentil.

\section{Primary metabolism compounds, energy content, and water-soluble proteins}

The primary metabolism compounds (moisture, lipids, proteins, fibers, carbohydrates) were quantified according to $\mathrm{AOAC}^{19}$ methods. Water-soluble proteins were determined as described previously ${ }^{20}$.

\section{Colorimetry and texturometry}

The colorimetric parameters $L^{*}, a^{*}$, and $b^{*}$ were determined as described by Lawless ${ }^{21}$ using a Minolta colorimeter (CR-300; Konica Minolta, Chiyoda, Tokyo, Japan). It was used, as determined by the CIE system (International
Lighting Commission), standard observer $10^{\circ}$ and illuminant C. The Hue angle $\left({ }^{\circ} \mathrm{H}\right)$ and the chroma $(\mathrm{C})$ were calculated according to Equations 2 and 3, respectively ${ }^{22}$.

$$
\begin{aligned}
& \text { o } \mathrm{H} \arctan \mathrm{b}^{* /} \\
& \mathrm{C}^{2}=\left(\mathrm{a}^{2}+\mathrm{b}^{2}\right)
\end{aligned}
$$

Texturometric analysis was performed on 20 replicates of individual lentils using a texture analyzer (Model TA.XTplus; Stable Micro Systems, Godalming, UK) ${ }^{23}$. A compression of $80 \%$ was used with a cylindrical probe 40 $\mathrm{mm}$ in diameter and test speed of $1 \mathrm{~mm} . \mathrm{s}^{-1}$, in two cycles, using a $5 \mathrm{~kg}$ load cell.

\section{Determination of minerals and amino acids}

Minerals were quantified according to Souza et $\mathrm{al}^{24}$, in which $0.2 \mathrm{~g}$ of sample were weighed and $2 \mathrm{ml}$ of nitro-perchloric acid mixture (2: 1) (65\% nitric acid and 70\% perchloric acid) was added, slowly warming until $210^{\circ} \mathrm{C}$, and after, the sample was digested for 3 hours. The sample was cooled to $25^{\circ} \mathrm{C}$, transferred to $25 \mathrm{ml}$ volumetric flask and made up to volume with deionized water. It was stored in amber flasks and taken to the flame atomic absorption spectrophotometry on a GBC AAS 932 Plus Atomic Absorption Spectrophotometer. Three readings of water only (control) were taken after cooking in order to reach conclusions about possible metal contamination. The reading of the control sample (water) was necessary in order to detect any species of metal contamination in the sample, since if there were, it could result in spurious findings. No water readings (control) showed metal contamination, therefore, the mineral evaluations exposed in this work were exclusively the result of the lentil.

Amino acids were identified according to Ravindranet $\mathrm{al}^{25}$ where $40 \mathrm{mg}$ of proteins were hydrolyzed with $10 \mathrm{ml}$ of hydrochloric acid at $110 \pm 4{ }^{\circ} \mathrm{C}$ for $24 \mathrm{~h}$ in vacuum sealed glass ampoules, and were quantified in an ion exchange High Performance/Pressure Liquid Chromatography (HPLC) system.

\section{Determination of antioxidant capacity, phenolic compounds, and antinutritional factors (phytates and tannins)}

Antioxidant capacity was determined by using 2,2-diphenyl1-picrylhydrazyl (DPPHmethod) described by Brand-Williams et $\mathrm{al}^{26}$ and the 2,2'-azino-bis (3-ethylbenzothiazoline-6-sulfonic acid; ABTS) method by Re and Philip ${ }^{27}$. Total and individual phenolic compounds were determined as described by NasarAbbas et $\mathrm{al}^{28}$. Total anthocyanins were measured according to Abdel-Aal and $\mathrm{Hucl}^{29}$.

Tannins were quantified according to the method of NassarAbbas et $\mathrm{a}^{28}$ in which $100 \mathrm{mg}$ of Polyvinyl Polypyrrolidone (PVPP) was weighed and placed in falcon $15 \mathrm{~mL}$ conical centrifuge tubes, adding $1 \mathrm{~mL}$ of deionized water and $1 \mathrm{~mL}$ of sample extract. Samples were stirred for 15 seconds and held at $5{ }^{\circ} \mathrm{C}$ for $15 \mathrm{~min}$. Then they were centrifuged for $15 \mathrm{~min}$ at $7500 \mathrm{x}$ $\mathrm{g}$. The supernatant was collected and the non-tannic phenolic compounds were determined. Tannins were determined by 
subtracting the total phenols from the non-tannic compounds.

Phytic acid (phytate) content was determined by the methodology proposed by Haug \& Lantzsch ${ }^{30}$. To carry out the methodology, homogenization of $0.015 \mathrm{~g}$ samples with 2 $\mathrm{mL}$ of $0.2 \mathrm{M}$ hydrochloric acid for 30 minutes was conducted. Subsequently, centrifugation was performed at $17200 \mathrm{rpm}$ for 15 minutes at $24^{\circ} \mathrm{C} .0 .5 \mathrm{~mL}$ of the supernatant was collected and transferred to Eppendorf by adding $1 \mathrm{~mL}$ of $\mathrm{FeCl}_{3}$. The Eppendorf was kept in a water bath at $90{ }^{\circ} \mathrm{C}$ for 30 minutes. After this period at high temperature, centrifugation was performed for 15 minutes at $3.000 \mathrm{~g}$ at $24^{\circ} \mathrm{C}$. Subsequently, a $0.5 \mathrm{~mL}$ aliquot of the supernatant was transferred to another Eppendorf, to which $0.75 \mathrm{~mL}$ of bipyridine was added. The samples were read in a spectrophotometer with a $515 \mathrm{~nm}$ wavelength.

\section{Statistical analyses}

A completely randomized design in a bifactorial scheme was used in the present study. Atypical values (outliers) were identified and removed from the database ${ }^{31}$. The data were analyzed for normality using the Shapiro-Wilk test. Homoscedasticity was identified by the Hartley's test. Independence of the residuals was determined by graphical analysis and subjected to ANOVA and the F-test $(\mathrm{P} \leq 0.05)$. Treatment effects were compared by the Tukey's test $(\mathrm{P} \leq 0.05)$. The effect of hydration was compared by the Dunnett's test $(\mathrm{P} \leq 0.05)$.

\section{RESULTS}

Effect of water temperature on the hydration curve

The hydration curve for raw lentils is shown in figure

1. For maximum hydration, lentils required $240 \mathrm{~min}$ or 180 min soaking in water at $25 \pm 2{ }^{\circ} \mathrm{C}$ or $90 \pm 5{ }^{\circ} \mathrm{C}$, respectively. Therefore, hydration time decreased with increasing the initial water temperature.

Lentils without pre-hydration required $15 \mathrm{~min}$ to be cooked. In contrast, hydrated lentils needed only $8 \mathrm{~min}$ to be fully cooked. Soaking/hydration optimized lentil preparation for cooking.

\section{Effects of hydration on primary metabolism compounds, energy, and water-soluble protein content}

Values in \% dry basis are summarized in table 1. Temperature elevation and discarding the hydration water reduced total protein content. Raw lentils had the lowest soluble protein content. For this reason, they required prolonged hydration to ensure the highest availability of soluble protein. LCSH had relatively low soluble protein content, and differences between samples were statistically significant. That result was likely due to the fact that lentils had not been previously hydrated, reducing the mobilization of water-soluble proteins out of the lentil. As proteins are closely linked to starch, when lentils begin cooking, the starch gelatinized, making it difficult to mobilize soluble proteins to the cooking water.

It was observed that LCA90 lentils obtained lower caloric values, indicating that exposure to high hydration temperature promotes maintenance of starch integrity inside of the lentil.

The highest ash content was observed in LCA90 (3.4\%), but the lowest was observed in LSA90 (2.3\%), likely promoted by excluding the soaking water for cooking.

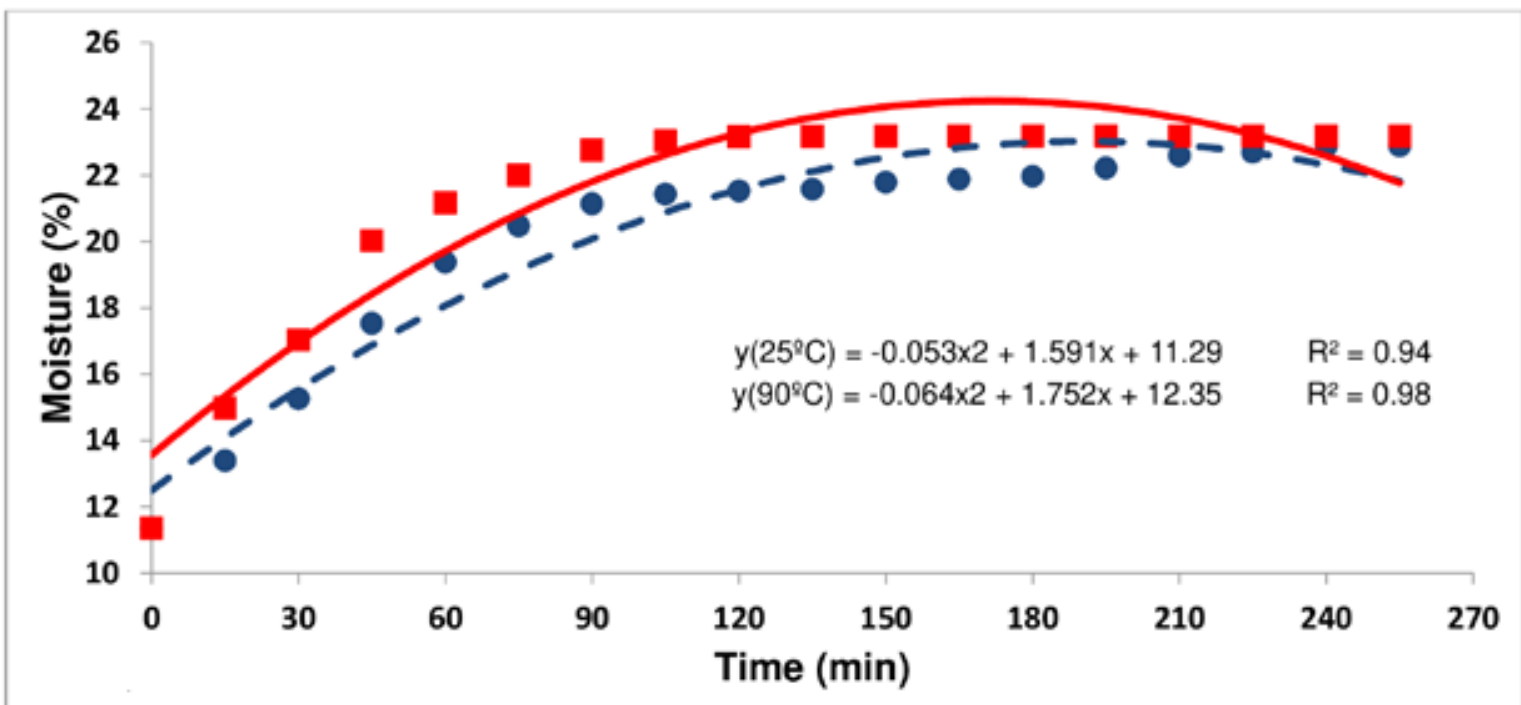

- Moisture content in grains soaked in hydration water at an initial temperature of $25 \pm 2{ }^{\circ} \mathrm{C}$. - Moisture content in grains soaked in hydration water at an initial temperature of $90 \pm 2{ }^{\circ} \mathrm{C}$.

Figure 1: Moisture percentage of raw lentils during hydration. 


\section{Effects of hydration on the colorimetric and texturometric parameters}

Lentils visually presented with a green color $\left(a^{*}<0\right)$; nevertheless, only raw lentils experimentally showed a negative $a^{*}$ value (Table 2). Samples showed a yellow tint, with Hue angle falling between $79.68^{\circ} \mathrm{H}$ and $99.7^{\circ} \mathrm{H}$. Untreated raw lentil had relatively higher brightness $\left(\mathrm{L}^{*}=\right.$ 86.55) than the treated lentils. Cooking significantly darkened lentil tonality as indicated by the chroma values (range: 14.35-23.60).
Table 2 summarizes the texturometric parameters for cooked lentils. The lowest hardness values were obtained for cooked lentils after soaking (LCA25 and LCA90). Hydration ensured proper water permeation within lentils and tenderness after cooking.

Cohesiveness differed among samples, ranging from 0.17 to 0.30. The lowest values were obtained for the hydrated lentils.

Chewiness was comparatively higher in non-hydrated lentils (1.26 Nmm-1) than soaked lentils. Therefore, less energy was needed to chew hydrated lentils. In lentils, this parameter was strongly correlated with hardness $(r=0.98)$.

Table 1. Effects of hydration on the primary metabolism compounds, energy value, and water-soluble protein content of raw and cooked lentils.

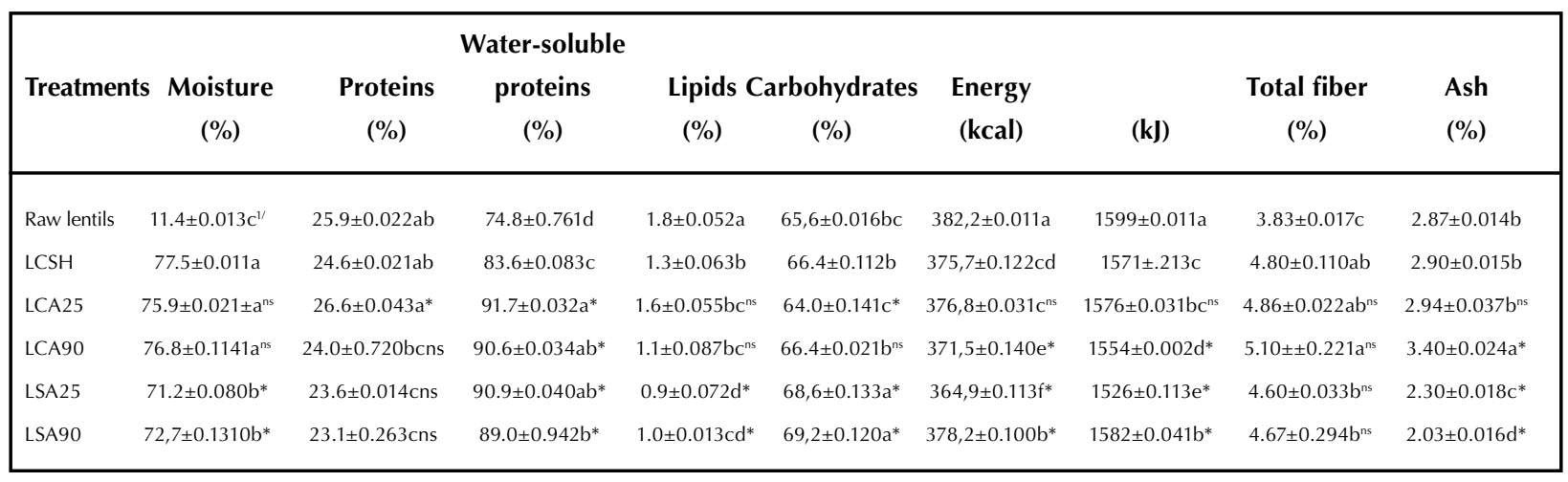

1/ Mean of three replicates \pm standard deviation. Same letter in a column indicates differences are not significant according to Tukey's test $(\mathrm{P}>0.05) .{ }^{*}$ orns, significant or not significant compared with control LCSH (lentils cooked without hydration) according to Dunnett's test (P $\leq 0.05)$. LSA25 and LCA25 refer to cooked lentils without or with hydration water at an initial temperature of $25^{\circ} \mathrm{C}$, respectively; LSA90 and LCA90 refer to cooked lentils without or with hydration water at an initial temperature of $90^{\circ} \mathrm{C}$, respectively.

Table 2. Effects of hydration on technological parameters.

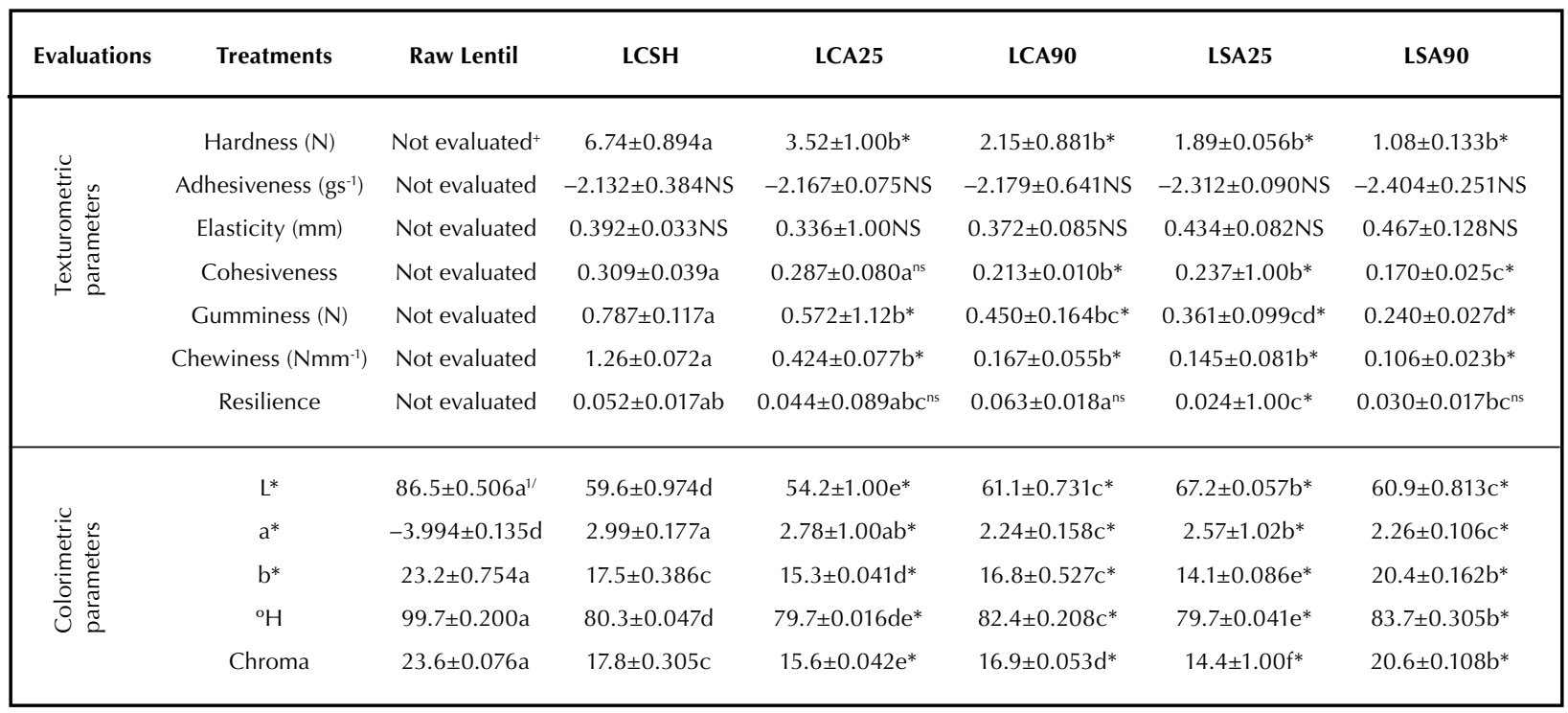

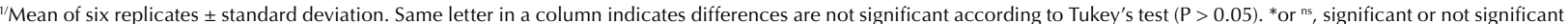

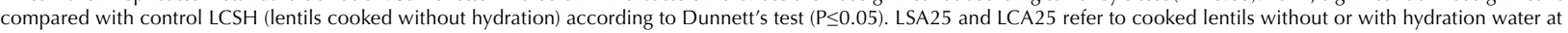

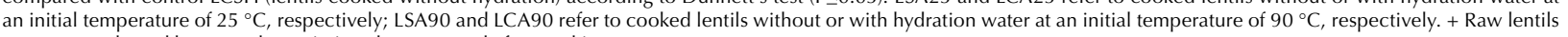
were not evaluated because the grain is only consumed after cooking. 
Table 3. Effects of hydration on mineral composition of raw or cooked lentils.

\begin{tabular}{|c|c|c|c|c|c|c|c|c|}
\hline Raw lentils & $8.47 \pm 0.023 \mathrm{a}^{1 /}$ & $1.04 \pm 0.154 \mathrm{ab}$ & $0.743 \pm 0.194 \mathrm{NS}$ & $226 \pm 0.027 d$ & $92.2 \pm 0.022 \mathrm{bcd}$ & $1.36 \pm 0.023 b$ & $432 \pm 0.027 d$ & $121 \pm 0.100 \mathrm{ab}$ \\
\hline $\mathrm{LCSH}$ & $8.38 \pm 0.029 b c$ & $1.05 \pm 0.439 a b$ & $0.610 \pm 0.041 \mathrm{NS}$ & $253 \pm 0.029 \mathrm{c}$ & $94.8 \pm 0.023 b c$ & $1.04 \pm 0.020 \mathrm{e}$ & $493 \pm 0.023 b$ & $129 \pm 0.013 a$ \\
\hline LCA90 & $8.39 \pm 0.037 b c^{n s}$ & $0.984 \pm 0.270 b c^{\mathrm{ns}}$ & $0.719 \pm 0.136 \mathrm{NS}$ & $299 \pm 0.016 \mathrm{a}^{*}$ & $103 \pm 0.020 a b^{n s}$ & $1.48 \pm 0.021 \mathrm{a}^{*}$ & $512 \pm 0.028 a^{*}$ & $129 \pm 0.019 a^{n s}$ \\
\hline LSA25 & $8.35 \pm 1.00 \mathrm{c}^{\mathrm{ns}}$ & $0.903 \pm 0.074 \mathrm{~cd}^{*}$ & $0.626 \pm 0.098 \mathrm{NS}$ & $222 \pm 0.077 d^{*}$ & $86.3 \pm 0.098 \mathrm{~cd}^{\mathrm{ns}}$ & $1.41 \pm 0.083 b^{*}$ & $442 \pm 1.02 c^{*}$ & $119 \pm 1.02 a b^{n s}$ \\
\hline LSA90 & $8.16 \pm 0.027 d^{*}$ & $0.826 \pm 0.066 \mathrm{~d}^{*}$ & $0.587 \pm 0.113 \mathrm{NS}$ & $193 \pm 0.029 \mathrm{e}^{*}$ & $80.9 \pm 0.107 d^{*}$ & $1.18 \pm 0.020 \mathrm{~d}^{*}$ & $266 \pm 0.021 \mathrm{e}^{*}$ & $115 \pm 0.204 b^{*}$ \\
\hline
\end{tabular}

${ }^{1 /}$ Mean of three replicates \pm standard deviation. Same letter in a column indicates differences are not significant according to Tukey's test $(\mathrm{P}>0.05) .{ }^{*}$ orns, significant or not significant compared with control LCSH (lentils cooked without hydration) according to Dunnett's test (P $\leq 0.05)$. LSA25 and LCA25 refer to cooked lentils without or with hydration water at an initial temperature of $25^{\circ} \mathrm{C}$, respectively; LSA90 and LCA90 refer to cooked lentils without or with hydration water at an initial temperature of $90^{\circ} \mathrm{C}$, respectively.

\section{Effects of hydration on the colorimetric and texturometric parameters}

Lentils visually presented with a green color $\left(a^{*}<0\right)$; nevertheless, only raw lentils experimentally showed a negative $a^{*}$ value (Table 2). Samples showed a yellow tint, with Hue angle falling between $79.68^{\circ} \mathrm{H}$ and $99.7^{\circ} \mathrm{H}$. Untreated raw lentil had relatively higher brightness $\left(L^{*}=86.55\right)$ than the treated lentils. Cooking significantly darkened lentil tonality as indicated by the chroma values (range: 14.35-23.60).

Table 2 summarizes the texturometric parameters for cooked lentils. The lowest hardness values were obtained for cooked lentils after soaking (LCA25 and LCA90). Hydration ensured proper water permeation within lentils and tenderness after cooking.

Cohesiveness differed among samples, ranging from 0.17 to 0.30 . The lowest values were obtained for the hydrated lentils.

Chewiness was comparatively higher in non-hydrated lentils $\left(1.26 \mathrm{Nmm}^{-1}\right)$ than soaked lentils. Therefore, less energy was needed to chew hydrated lentils. In lentils, this parameter was strongly correlated with hardness $(r=0.98)$.

\section{Effects of hydration on mineral and amino acid composition}

Table 3 shows that lentil processing significantly changed the availability of all inorganic compounds. Hydration water at the $90 \pm 2{ }^{\circ} \mathrm{C}$ increased mineral leaching into the soaking water. LCA90 contained relatively higher $\mathrm{Cu}, \mathrm{P}, \mathrm{Mg}, \mathrm{Mn}$, and Ca levels. Discarding the hydration water reduced the mineral content as observed in LSA90, which presented with comparatively lower $\mathrm{Fe}, \mathrm{Zn}, \mathrm{Cu}, \mathrm{P}, \mathrm{Mg}, \mathrm{K}$, and Ca levels.

Table 4 shows that glutamic and aspartic acids were the most abundant of amino acids in the lentils. Hydration increased the availability of aspartic acid, glutamic acid, glycine, arginine, threonine, methionine, leucine, and isoleucina, especially in samples cooked in the hydration water preheated to $90 \pm 2{ }^{\circ} \mathrm{C}$ (LCA90).
Positive correlations were observed between amino acids (Table 4) and bioactive compounds (Table 5); between individual phenolic compounds and glycine $(r=0.92)$, proline $(r=0.89)$, or lysine $(r=0.94)$; between total phenolic compounds or DPPH and proline $(r=0.93$; $r=0.95$, respectively); and between anthocyanins, and between total or individual phenolic compounds and lysine $(r=0.85 ; r=0.92 ; r=0.97$, respectively). Thus, potential interactions existed between bioactive compounds and amino acids in lentils.

\section{Effects of hydration on antioxidant activity, phenolic compounds, and antinutritional factors}

As shown in table 5, cooking and eliminating the hydration water significantly reduced both bioactive compounds and antioxidant activity. However, individual phenolic compounds in LCSH were conserved possibly because they are heat-resistant and were not eliminated in the hydration process. Because anthocyanins are water-soluble and cannot resist high temperatures, they leached into the hydration water and were discarded with it. Consequently, LSA90 presented low anthocyanin content $\left(1.55 \mathrm{mg} .100 \mathrm{~g}^{-1}\right)$. ABTS analysis of antioxidant activity generated significantly different values among treatments. LCSH had the highest ABTS content (1988.5 $\mu \mathrm{M}$ Troloxg $^{-1}$ ).

Table 5 indicates that phytate and tannins leached into, and may have been discarded with, hydration water. An important but negative effect of phytates is their binding to nutritionally important metal cations such as iron, magnesium, and calcium, effectively sequestering and reducing bioavailability. The lowest values were measured for LSA25 and LSA90 and these values significantly differed from those obtained following other treatments.

A negative correlation was found between tannin content and soluble protein $(r=-0.92)$ and between tannin content and carbohydrate levels $(r=-0.95)$. 
Table 4. Effects of hydration on amino acid composition of raw or cooked lentils.

\begin{tabular}{|c|c|c|c|c|c|c|}
\hline Amino acids & Raw lentils & LCSH & LCA25 & LCA90 & LSA25 & LSA90 \\
\hline Glutamic acid & $4.02 \pm 0.048 \mathrm{bc}$ & $3.67 \pm 0.024 c$ & $4.34 \pm 0.071 b^{*}$ & $4.93 \pm 0.020 \mathrm{a}^{*}$ & $4.24 \pm 0.040 b^{*}$ & $4.00 \pm 0.023 b c^{*}$ \\
\hline Serine & $1.00 \pm 0.013 \mathrm{ab}$ & $1.24 \pm 0.016 \mathrm{ab}$ & $1.24 \pm 0.089 \mathrm{a}^{\mathrm{ns}}$ & $1.00 \pm 0.021 a b^{n s}$ & $0.805 \pm 0.030 b^{*}$ & $1.36 \pm 0.202 \mathrm{a}^{\mathrm{ns}}$ \\
\hline Histidine & $0.249 \pm 0.014 \mathrm{NS}$ & $0.421 \pm 0.201 \mathrm{NS}$ & $0.412 \pm 0.090 \mathrm{NS}$ & $0.207 \pm 0.107 \mathrm{NS}$ & $0.094 \pm 1.00 \mathrm{NS}$ & $0.400 \pm 0.016 \mathrm{NS}$ \\
\hline Arginine & $1.94 \pm 0.023 \mathrm{ab}$ & $2.04 \pm 0.301 \mathrm{ab}$ & $2.38 \pm 0.051 \mathrm{a}^{\mathrm{ns}}$ & $1.76 \pm 0.209 \mathrm{~b}^{\mathrm{ns}}$ & $1.70 \pm 0.081 b^{\mathrm{ns}}$ & $2.19 \pm 0.100 \mathrm{ab}^{\mathrm{ns}}$ \\
\hline Threonine & $1.51 \pm 0.109 a$ & $0.814 \pm 0.200 \mathrm{~b}$ & $1.64 \pm 0.044 a^{*}$ & $1.40 \pm 0.104 a^{*}$ & $0.796 \pm 0.140 b^{\mathrm{ns}}$ & $0.911 \pm 0.210 \mathrm{~b}^{\mathrm{ns}}$ \\
\hline Alanine & $1.14 \pm 0.122 \mathrm{NS}$ & $1.00 \pm 0.109 \mathrm{NS}$ & $1.12 \pm 1.00 \mathrm{NS}$ & $0.908 \pm 0.206 \mathrm{NS}$ & $1.24 \pm 0.066 \mathrm{NS}$ & $1.13 \pm 0.101 \mathrm{NS}$ \\
\hline Methionine & $0.211 \pm 0.108 \mathrm{ab}$ & $0.110 \pm 0.025 b$ & $0.300 \pm 1.02 \mathrm{ab}^{*}$ & $0.438 \pm 0.134 \mathrm{a}^{*}$ & $0.214 \pm 1.02 \mathrm{ab}^{\mathrm{ns}}$ & $0.162 \pm 0.023 b^{n s}$ \\
\hline Cysteine & $0.202 \pm 0.122 \mathrm{NS}$ & $0.202 \pm 0.155 \mathrm{NS}$ & $0.231 \pm 1.04 \mathrm{NS}$ & $0.38 \pm 0.117 \mathrm{NS}$ & $0.333 \pm 1.00 \mathrm{NS}$ & $0.251 \pm 0.102 \mathrm{NS}$ \\
\hline Isoleucine & $1.04 \pm 0.171 b$ & $1.03 \pm 0.156 b$ & $1.20 \pm 0.265 b^{\mathrm{ns}}$ & $2.17 \pm 0.109 \mathrm{a}^{*}$ & $1.30 \pm 0.087 b^{n s}$ & $1.13 \pm 0.400 b^{\mathrm{ns}}$ \\
\hline Leucine & $1.00 \pm 0.190 b$ & $1.62 \pm 0.101$ & $1.87 \pm 0.164 \mathrm{a}^{\mathrm{ns}}$ & $2.08 \pm 0.200 \mathrm{a}^{*}$ & $2.04 \pm 1.00 a^{*}$ & $1.91 \pm 0.141 a^{\mathrm{ns}}$ \\
\hline Phenylalanine & $1.4 \pm 0.209 \mathrm{ab}$ & $1.2 \pm 0.100 \mathrm{~b}$ & $1.49 \pm 0.500 a b^{\text {ns }}$ & $1.30 \pm 0.201 \mathrm{ab}^{\mathrm{ns}}$ & $1.62 \pm 1.06 \mathrm{a}^{*}$ & $1.37 \pm 0.100 a b^{\text {ns }}$ \\
\hline Lysine & $0.5 \pm 0.107 \mathrm{~b}$ & $0.9 \pm 0.104 a b$ & $0.941 \pm 1.00 \mathrm{ab}^{\mathrm{ns}}$ & $0.401 \pm 0.101 b^{*}$ & $1.20 \pm 1.02 \mathrm{a}^{\mathrm{ns}}$ & $1.49 \pm 0.204 \mathrm{a}^{*}$ \\
\hline
\end{tabular}

${ }^{1 /}$ Mean of three replicates \pm standard deviation. Same letter in a column indicates differences are not significant according to Tukey's test $(\mathrm{P}>0.05) .{ }^{*} \mathrm{or}^{\mathrm{ns}}$, significant or not significant compared with control LCSH (lentils cooked without hydration) according to Dunnett's test (P $\leq 0.05)$. LSA25 and LCA25 refer to cooked lentils without or with hydration water at an initial temperature of $25^{\circ} \mathrm{C}$, respectively; LSA90 and LCA90 refer to cooked lentils without or with hydration water at an initial temperature of $90^{\circ} \mathrm{C}$, respectively.

Table 5. Effects of hydration on antioxidant activity, phenolic compounds, phytates and tannins.

\begin{tabular}{|c|c|c|c|c|c|c|c|}
\hline Treatments & $\begin{array}{c}\text { Anthocyanins } \\
\left(\mathbf{m g} .100 \mathrm{~g}^{-1}\right)\end{array}$ & $\begin{array}{c}\text { DPPH } \\
\left(\mu \mathrm{M} . \text { Troloxg }^{-1}\right)\end{array}$ & $\begin{array}{c}\text { ABTS } \\
\left(\mu \mathrm{M} . \text { Troloxg }^{-1}\right)\end{array}$ & $\begin{array}{c}\text { Total phenols } \\
\text { (mg tannic acid.g-1) }\end{array}$ & $\begin{array}{l}\text { Simple phenols } \\
\text { (mg tannic acid.g-1) }\end{array}$ & $\begin{array}{c}\text { Phytate } \\
\left.\text { (mg phytic acid.g }{ }^{-1}\right)\end{array}$ & $\begin{array}{c}\text { Tannins } \\
\left.\text { (mg tannic acid.g }{ }^{-1}\right)\end{array}$ \\
\hline Raw lentils & $1.80 \pm 0.055 \mathrm{a}^{1 /}$ & $2.36 \pm 0.041 \mathrm{a}$ & $2023 \pm 0.708 a$ & $30.5 \pm 0.236 \mathrm{a}$ & $4.06 \pm 0.022 \mathrm{a}$ & $38.9 \pm 0.115 \mathrm{a}^{1 /}$ & $26.9 \pm 0.038 \mathrm{a}$ \\
\hline $\mathrm{LCSH}$ & $1.76 \pm 0.030 \mathrm{a}$ & $2.19 \pm 0.066 b$ & $1988 \pm 1.24 b$ & $25.9 \pm 2.24 b$ & $4.02 \pm 0.019 a$ & $38.8 \pm 0.082 \mathrm{ab}$ & $21.1 \pm 0.017 b$ \\
\hline LCA25 & $1.75 \pm 0.046 \mathrm{a}^{\mathrm{ns}}$ & $2.23 \pm 0.080 b^{\mathrm{ns}}$ & $1964 \pm 0.044 c^{*}$ & $19.8 \pm 1.00 c^{*}$ & $3.71 \pm 0.040 \mathrm{~b}^{*}$ & $38.5 \pm 0.070 b^{*}$ & $16.1 \pm 1.00 \mathrm{c}^{*}$ \\
\hline LCA90 & $1.70 \pm 0.028 a b^{n s}$ & $2.26 \pm 0.083 b^{*}$ & $1906 \pm 0.110 d^{*}$ & $20.7 \pm 1.99 c^{*}$ & $3.99 \pm 0.101 a^{\mathrm{ns}}$ & $38.6 \pm 0.066 \mathrm{~b}^{\mathrm{ns}}$ & $12.0 \pm 0.012 \mathrm{~cd}^{*}$ \\
\hline LSA25 & $1.63 \pm 0.017 b c^{*}$ & $2.19 \pm 0.071 b^{n s}$ & $1297 \pm 1.00 f^{*}$ & $8.83 \pm 0.484 d^{*}$ & $3.39 \pm 1.02 \mathrm{c}^{*}$ & $37.1 \pm 0.083 c^{*}$ & $5.44 \pm 0.070 \mathrm{e}^{*}$ \\
\hline LSA90 & $1.55 \pm 0.058 c^{*}$ & $2.24 \pm 0.049 b^{n s}$ & $1319 \pm 0.029 \mathrm{e}^{*}$ & $9.68 \pm 0.470 d^{*}$ & $3.41 \pm 0.036 c^{*}$ & $36.7 \pm 0.069 \mathrm{~d}^{*}$ & $3.95 \pm 0.032 \mathrm{e}^{*}$ \\
\hline
\end{tabular}

${ }^{1 / M e a n}$ of three replicates \pm standard deviation. Same letter in a column indicates differences are not significant according to Tukey's test (P>0.05). * ${ }^{\text {ns }}{ }^{\text {, }}$ significant or not significant compared with control LCSH (lentils cooked without hydration) according to Dunnett's test (P $\leq 0.05)$. LSA25 and LCA25 refer to cooked lentils without or with hydration water at an initial temperature of $25{ }^{\circ} \mathrm{C}$, respectively; LSA90 and LCA90 refer to cooked lentils without or with hydration water at an initial temperature of $90{ }^{\circ} \mathrm{C}$, respectively. 


\section{DISCUSSION}

We observed that a higher temperature of hydration water reduced the length to completely hydrate the lentils. After soaking for $180 \mathrm{~min}$, the hydration coefficients of pre-hydrated lentils at $25 \pm 2{ }^{\circ} \mathrm{C}$ or $90 \pm 2{ }^{\circ} \mathrm{C}$, respectively, were $189.34 \%$ or $202.60 \%$, higher than previously reported values $^{32}$. Thus, hydration improves with increasing the initial temperature of the soaking water. Accordingly, high temperatures reportedly shorten the time to hydrate beans ${ }^{33}$.

The time required for cooking was also reduced as a result of presoaking, because the high temperature of hydration water also promotes lentil precooking, optimizing preparation time.

Huma et $\mathrm{al}^{33}$ and Joshi et $\mathrm{a} \mathrm{l}^{8}$ reported that soaking grains reduced their cooking time. Thus, reducing the soaking time is preferable because prolonged hydration may facilitate growth of pathogenic microorganisms ${ }^{8}$.

Lentils naturally have water in their composition (represented by the moisture content), thus, the increase of the external environment temperature promoted water vapor expansion inside the lentil, increasing the intragranular porosity, promoting empty spaces inside the lentil. Subsequently, the formed spaces were filled with hydration water, which at $90^{\circ} \mathrm{C}$ also promoted the elasticity of the integument fibers, although it did not prevent rupture.

A certain proportion of the proteins in Fabaceae are used for storage, these are soluble proteins, representing the hydrophilic fraction of the total proteins of the grain ${ }^{34}$.

The reduced total protein content after eliminating hydration water and the increasing soluble protein content by maintaining hydration water provides us with one of the most important data points when it comes to lentils, which is the solubility and large capacity to migrate to soaking water. Since lentils are classified as a proteic grain, this data is fundamental for understanding lentil behavior when submitted to the presoaking process. In technological matters the migration of proteins to hydration water and its maintenance in cooking promotes broth gelation and thickening, which is a feature appreciated by most consumers, especially associated with the reduced cooking time. Raw lentils had the lowest soluble protein content, strengthening what was previously reported. Huma et $\mathrm{al}^{33}$ reported that high temperature negatively affects the total protein content of lentils. According to Rockenbach et a ${ }^{11}$, the levels of soluble proteins derived from beans were similarly found to increase with increasing the temperature of the hydration water, since the increase of the hydration water temperature increases the leaching of compounds to the outside of the lentil because it presents increased intragranular porosity, facilitating the exit of compounds.

Legumes normally have high caloric values ${ }^{4}$, like those observed at table 1, but lower values (1995kJ) than these observed by Padovani et $\mathrm{al}^{35}$ for North American Lens culinaris Medik. However, lentils soaked in water at an initially higher temperature yielded relatively higher energy values than those soaked in water at lower temperatures.
The minerals in the lentils were leached and dispersed in the soaking water. Therefore, discarding this water significantly reduced ash content.

In lentils soaked in hydration water at $90 \pm 2{ }^{\circ} \mathrm{C}$ and cooked with this water (LCA90) a high ash content was observed, similar to what was reported by Toledo and Canniatti-Brazaca ${ }^{36}$ who cooked samples with hydration water. However, the lowest value was observed in LSA90 $(2.03 \%)$, exposing that discarding hydration water promotes reduction of minerals, because these elements are leached by the water, and disposed of. This result supports the findings reported by Wang et a $\left.\right|^{15}$. Total ash content in the raw lentil $(2.87 \%)$ was higher than that reported by Padovani et a ${ }^{35}$ (2.61 and $2.67 \%$ ), but lower than the $4.62 \%$ and $5.72 \%$ levels reported by Garcia et $\mathrm{a}^{37}$ in cowpea, a grain belonging to the same taxonomic family.

A negative $a^{*}$ value for raw lentils (Table 2 ) was observed, indicating green color. These values are similar to those reported by Zhang et $\mathrm{a}^{38}$ in green lentil cultivars. Thermic processing leads to the development of a reddishbrown color $\left(a^{*}>0\right)$ in lentils; this color has been proposed to be associated with the tannin content ${ }^{39}$, as well as the degradation of the tegument pigmenting agents promoted by temperature increases. Another factor to consider is the disruption of the integumentary fibers causing elasticity and reducing lentil brightness. The Hue angle was close to 90 ${ }^{\circ} \mathrm{H}$, and according to Del Bemet $\mathrm{al}^{40}$, values near $90{ }^{\circ} \mathrm{H}$ indicate yellowish coloration. The integument accounts for the green color of lentils, but their cotyledons are yellow. If the proportion of cotyledon exceeds that of the integument, then the lentils appear yellow because their husks are separated from the endosperm during cooking. In raw lentils, the integument is thin and the yellow cotyledons are more readily visible. It was possible to verify that the thermal processing reduced the brightness of lentil, as observed in table 2, but in raw lentils, values are closer than those reported by Zhang et $\mathrm{a}^{38}$ for a Canadian lentil cultivar $\left(\mathrm{L}^{*}=\right.$ 85.15). Chroma values, which are low or approach zero, are indicative of gray lentil tones.

Regarding the values of the texturometric parameters, in table 2 it is possible to observe that in general, lentil texture was dependent on hydration, because softness is related with the soaking time and the temperature of hydration water. The hydration process promoted distribution of water in the lentil and tenderness after cooking. Similar results were reported by Joshi et $\mathrm{al}^{8}$. The lowest values for cohesiveness were observed in hydrated lentils, thus it is possible to observe that the hydration process can guarantee adequate palatability. Even lower values were reported by Rockenbach et $\mathrm{al}^{11}(0.14-0.16)$. Chewiness, lower in hydrated lentils, refers to the force and number of chews required to enable a food to be swallowed, and this parameter is strongly related to hardness. Both chewiness and hardness depend on presoaking and cooking of lentil.

Discarding the hydration water reduced the mineral content of lentils (Table 3), corroborating previous 
observations36. Heat treatment reportedly diminishes the mineral content of lentils ${ }^{4}$. We found iron content in raw lentils to be $8.47 \mathrm{mg} 100 \mathrm{~g}^{-1}$ which was higher than that reported by Johnson et $\mathrm{al}^{1}\left(54.6-68.3 \mathrm{mg} \cdot \mathrm{kg}^{-1}\right)$. However, this value was similar to that reported by Wang et al ${ }^{15}$. LCA25 had $8.46 \mathrm{mg} 100 \mathrm{~g}^{-1} \mathrm{Fe}$, which was significantly higher than that

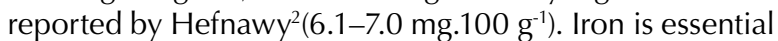
for many biochemical reactions and physiological processes, including cell growth, energy supply, and oxygen transport.

Zinc content in raw lentils was $1.04 \mathrm{mg} .100 \mathrm{~g}^{-1}$. Different values have been reported previously; for example, Angelova et $\mathrm{al}^{41}$ reported $0.47 \mathrm{mg} . \mathrm{kg}^{-1} \mathrm{Zn}$. Hefnawy ${ }^{2}$ and Lazarte et $\mathrm{al}^{42}$ reported 3-4 mg.100 $\mathrm{g}^{-1} \mathrm{Zn}$ in cooked lentils.

Fabaceae have low levels of free phosphorus but substantial quantities of phytate. Relatively higher phosphorus content was found in LCA90 (299 mg.100 g $\mathrm{g}^{-1}$ ). The lowest phosphorus level was measured for LSA90 (193 mg.100 g-1). Raw lentils contained 226 mg.100 g g $^{-1}$ phosphorus, which was below previously reported values $2,3,4,5,6,7,8,9,10,11,12,13,14,15$.

LCA90 had a potassium content of $512 \mathrm{mg} .100 \mathrm{~g}^{-1}$ which was equal to that reported by Hefnawy ${ }^{2}$. Potassium levels significantly vary among species. Although potassium is not integrated into plant structures, it plays a key role in physiological and biochemical processes. Calcium content in the lentils ranged from 115 to $129 \mathrm{mg} .100 \mathrm{~g}^{-1}$ which was similar to values reported by Lazarte et $\mathrm{al}^{42}$, but higher than those reported by Somavilla et al $^{43}$ (20.17 to 56.89 $\left.\mathrm{mg} .100 \mathrm{~g}^{-1}\right)$. Porres et $\mathrm{al}^{44}$ reported markedly lower calcium levels in Spanish lentils than those we found in this study.

Table 4 shows amino acids composition. It was observed that glutamic and aspartic acid were higher than all the other protein-derived nitrogen-containing compounds. According to Toledo and Canniatti-Brazaca ${ }^{36}$, the available amino acid content was found to be relatively higher in pre-hydrated, cooked beans, possibly because lentils were exposed only to a high temperature for a short time. In this sense, Hefnawy ${ }^{2}$ reported that heating reduces amino acid availability. Similar or higher amino acid content in LCA90 can be explained by degradation of both total and soluble proteins, resulting in the liberation of amino acids in the soaking water, which was used for cooking. The correlation between soluble protein and amino acids was significant $(r=0.98)$.

We found that antioxidant activity and levels of bioactive compounds were reduced by cooking and discarding the hydration water, as also reported by Ranilla et al ${ }^{45}$. Because antioxidant compounds in lentils' husk could be extracted with hot water ${ }^{3}$, hydration before cooking may liberate antioxidants, but the hydration water must be kept. Discarding the hydration water causes reduction of anthocyanins too, especially in lentils hydrated at high temperature. Importantly, anthocyanins are present in whole lentils and their fractions ${ }^{15}$ and are determinants of lentil quality as they are colored, ranging from red to purple.

Besides anthocyanins content, antioxidant activity determined by the ABTS method is reduced by the cooking process. These results corroborate those of Silva et al ${ }^{46}$ who reported that cooking beans reduced the antioxidant capacity compared to that of the grain in natura.

It was found that cooking and elimination of hydration water profoundly reduced levels of the antinutritional factors (phytates and tannins) (Table 5). Our results corroborate those of Vidal-Valverdeet $\mathrm{al}^{39}$, who reported that tannins and phytates were extracted by hydration water and that cooking effectively reduces levels of antinutritional compounds $2,3,4,5,6,7,8,9,10,11,12,13,14,15$. Huma et $\mathrm{al}^{33}$ reported significant reductions in phytate and tannin content in lentils after soaking and pressure-cooking. In a study with Inga paterno (Fabaceae), Sánchez Mendoza et $\mathrm{al}^{47}$ reported a tannin content in the range of 1.46-1.51 $\mathrm{mg} \pm$ catechin eq. $\mathrm{g}^{-1}$ and a phytate content ranging from 2.04 to $2.66 \mathrm{mg}^{-1} \mathrm{~g}^{-1}$. These levels were lower than those determined for lentils.

Hydration lowers the content of anti-nutritional compounds by solubilizing them so that they may be discarded along with hydration water. Vidal-Valverdeet $\mathrm{al}^{39}$ reported that tannins can bind to proteins and carbohydrates reducing the nutritional quality of the legumes and their protein content ${ }^{34}$.

\section{CONCLUSION}

We observed that lentil hydration and cooking time decreased with higher soakingwater temperature. Lentils cooked without soaking were stickier, more elastic, and gummier than those soaked and cooked, and required relatively greater chewing force. Soaking and disposal of the hydration water significantly reduced levels of anti-nutritional factors. The maintenance of nutritional parameters is extremely important for metabolic maintenance, ensuring that biochemical processes occur properly and are capable of establishing a positive relationship with the physiological state of individuals. Phytates bind to metal cations; tannins bind with proteins and carbohydrates in lentils. Both substances reduce the bioavailability of these nutrients.

Based on these results, we suggest that lentils be cooked in hydration water that has been pre-heated to an initial temperature of $90^{\circ} \mathrm{C}$. This will ensure favorable lentil texture and color. Moreover, levels of minerals, bioactive compounds, antioxidants, and amino acid smay be maintained in the lentils. It is worth mentioning that although laboratory conditions were used for this study, with distilled water and pressure control in cooking, consumers can find the same results at home. For that, the consumer must place soaking grains in water at room temperature $\left(25^{\circ} \mathrm{C}\right)$ or in boiled water $\left(90^{\circ} \mathrm{C}\right)$ and after, cook lentils in a domestic pressure cooker, according to the procedures used in this study.

Acknowledgements. The authors thank the Coordination for the Improvement of Higher Education Personnel (CAPES), the National Council for Scientific and Technological Development (CNPq), the Foundation for Research Support of the Rio Grande do Sul State (FAPERGS), the Department of Science and Technology of the State of Rio Grande do 
Sul (SCT-RS), the Campaign Region University Center, the Food Technological Innovation Pole of the Southern Region, and the Pro-Rectory of Research, Innovation and Post-Graduate of the IFSul.

\section{REFERENCES}

1. Johnson CR, Thavarajah D, Combs JR, Gerald F, Thavarajah P. Lentil (Lens culinaris L.): A prebiotic-rich whole food legume. Food Res Int 2013; 51: 107-113.

2. Hefnawy TH. Effect of processing methods on nutritional composition and anti-nutritional factors in lentils (Lens culinaris). Ann Agric Sci 2011; 56: 57-61.

3. Oomah BD, Caspar F, Malcolmson LJ, Bellido AS Phenolics and antioxidant activity of lentil and pea hulls. Food Res Int 2011; 44: 436-441.

4. Miceli A, Miceli C. Effect of thermal treatments on vitality and physical characteristics of bean, chickpea and lentil. I Stored Prod Res 2012; 51: 86-91.

5. arrueto-Gonzalez NB. Bioavailability of minerals from leguminous sources. Rev Simbio-Logias 2008; 1: 174-183.

6. Shons PF, Leite AV, Novello D, Bernardi DM, Morato PN, Rocha LM et al. Lentil Protein Efficiency (Lens Culinaris) In The Development Of Wistar Rats. Braz I Food Nutr 2009; 20: 255-260.

7. Kouvoutsakis G, Mitsi C, Tarantilis PA, Polissiou MG, Pappas CS. Geographical differentiation of dried lentil seed (Lens culinaris) samples using Diffuse Reflectance Fourier Transform Infrared Spectroscopy (DRIFTS) and discriminant analysis. Food Chem 2014; 145: 1011-1014.

8. Joshi M, Adhikari B, Panozzo J, Aldred P. Water uptake and its impact on the texture of lentils (Lens culinaris). J Food Eng 2010; 100: 61-69.

9. Zia-Ul-Haq M, Ahmad S, Shad MA, Iqbal S, Qayum M, Ahmad $A$, et al. Compositional studies of lentil (Lens culinaris Medik) cultivars commonly grown in Pakistan. Pak J Bot 2011; 43: 1563-1567.

10. Ganesan K, Xu B. Polyphenol-rich lentils and their health promoting effects. Int J Mol Sci 2017; 18: 1-23.

11. Rockenbach R, Ávila B, Bragança G, Monks J, Peres W, Gularte $M$ et al. Effect of different hydration temperatures on the sensory, nutritional, and instrumental profile of black beans. Rev Chil Nutr 2018; 45: 144-152.

12. Kumar SK, Barpete S, Kumar J, Gupta P, Sarker A. Global lentil production: constraints and strategies. SATSA MukhapatraAnnual Technical 2013; 17: 1-13.

13. Dueñas M, Hernandez T, Estrella I. Changes in the content of bioactive polyphenolic compounds of lentils by the action of exogenous enzymes. Effect on their antioxidant activity. Food Chem 2007; 101: 90-97.

14. Bressani R, Mors RD, Flores R, Gómez BR. Evaluation of two methods to establish the content of polyphenols in raw and cooked beans, and their effect on protein digestibility. Archiv Latino Amer Nutr 1991; 16: 569-583.

15. Wang N, Hatcher DW, Toews R, Gawalko EJ. Influence of cooking and dehulling on nutritional composition of several varieties of lentils (Lens culinaris). LWT-Food Sci Technol 2009; 42: 842-848.

16. Vindiola OL, Seib PA, Hoseney RC. Accelerated development of the hard-to-cook state in beans. Cer Foods World 1986; 31: 538-552.

17. El-Refai AA, Harras HM, El-Nemr KM, Noaman MA. Chemical and technological Studies on faba bean seeds. I. Effect of storage on some physical and chemical properties. Food Chem 1988; 29: 27-39.

18. Lehn DN, Pinto LAA. Equilibrium isotherms and drying curves for paddy rice in storage silos. Agri Eng 2004; 12: 177-191.

19. Association of Official Analytical Chemists. Official Methods of Analysis of the AOAC. 18th ed. Washington, D.C., The Association, 2006.

20. Liu K, McWatters KH, Phillips RD. Protein insolubilization and thermal destabilization during storage as related to hard-to-cook defect in cowpeas. I Agric Food Chem 1992; 40: 2483-2487.

21. Lawless HT, Heymann H. Sensory evaluation of food: principles and practices. New York: Kluwer Academic/Plenum Publishers, 1998.

22. Harder MNC, Canniatti-Brazaca SG, Arthur V. Quantitative evaluation by a digital colorimeter of the color of the egg of laying hens fed with annatto (Bixa orellana). Port J Vet Sci 2007; 102: 339-342.

23. Bourne MC. Texture profile analysis. Food Technol 1978; 32: 62-72.

24. De Souza DM, Bassinello PZ, Nóbrega LNN. Scientific Methodology: Methodological improvement for microwave assisted digestion in mineral analysis of common bean Phaseolus vulgaris L. Embrapa Rice and Beans. Technical Announcement 196, Santo Antônio de Goiás, Brazil, 2010.

25. Ravindran V, Morel PCH, Rutherfurd SM, Thomas DV. Endogenous flow of amino acids in the avian ileum is increased by increasing dietary peptide concentrations. Brit J Nutr 2009; 101: 822-828.

26. Brand-Williams W. Cuvelier ME, Berset C. Use of free radical method to evaluate antioxidant activity. Lebens Wissen Technol 1995; 28: 25-30.

27. Re R, Philip $\mathrm{OH}$. Antioxidant activity applying an improved ABTS radical cation decolorization assay. Free Rad Biol Med 1999; 26: 123-127.

28. Nasar-Abbas SM, Plummer JA, Siddique KHM, White $P$, Harris $D$, Dods K. Cooking quality of faba bean after storage at high temperature and the role of lignins and other phenolics in bean hardening. Food Sci Technol 2008; 41: 1260-1267.

29. Abdel-Aal ESM, Hucl P. Composition and stability of anthocyanins in blue-grained wheat. I Agric Food Chem 2003; 51: 2174-2180.

30. Haug W, Lantzsch HJ. Sensitive method for the rapid determination of phytate in cereals and cereal products. I Sci Food Agric 2013; 34: 1423-1426.

31. Barnett V, Lewis T. Outliers in statistical data. John Wiley \& Sons, New York, 1994.

32. Khan MA, Rana IA, Ullah I, Jaffery S. Physicochemical characters and nutrient composition of some improved lines of lentils grown in Pakistan. J Food Comp Anal 1987; 1: 65-70.

33. Huma N, Anjum M, Sehar S, Issa KM, Hussain S. Effect of soaking and cooking on nutritional quality and safety of legumes. Nutr Food Sci 2008; 38: 570-577.

34. Granito $M$, Pérez $S$, Valero Y. quality of cooking, acceptability and glycemic index of enriched pasta with legumes. Rev Chil Nutr 2014; 41: 425-432.

35. Padovani RM, Lima DM, Colugnati FA, Rodriguez-Amaya DB. Comparison of proximate, mineral and vitamin composition of common Brazilian and US foods. J Food Comp Anal 2007; 20: 733-738.

36. De Toledo CF, Canniatti-Brazaca SG. Chemical and nutritional evaluation of Carioca beans (Phaseolus vulgaris L.) cooked by different methods. Food Sci. Technol 2008; 28: 355-360. 
37. Garcia $O E$, Infante $B$, Rivera CJ. Comparison of dietary fiber values between two varieties of cowpea (Vigna unguiculata L. Walp) of Venezuela, using chemical and enzymatic gravimetric methods. Rev Chil Nutr 2010; 37: 455-460.

38. Zhang B, Deng Z, Tang Y, Chen P, Liu R, Ramdath DD et al. Fatty acid, carotenoid and tocopherol compositions of 20 Canadian lentil cultivars and synergistic contribution to antioxidant activities. Food Chem 2014; 161: 296-304.

39. Vidal-Valverde C, Farias J, Estrella I, Gorospe MI, Ruiz R, Bacon J. Effect of processing on some antinutritional factors of lentils. J Agric Food Chem 1994; 42: 2291-2295.

40. Del Bem MS, Polesi LF, Sarmento SBS, Anjos C. Physicochemical and sensory properties of pasta prepared with legume flours hydrothermally treated. Braz J Food Technol 2012; 23: 101-110.

41. Angelova $V$, Ivanova $R$, Ivanov K. Accumulation of heavy metals in leguminous crops (bean, soybean, peas, lentils and gram). J Environ Prot Ecol 2003; 4: 787-795.

42. Lazarte CE, Carlsson NG, Almgren A, Sandberg AS, Granfeldt Y. Phytate, zinc, iron and calcium content of common Bolivian food, and implications for mineral bioavailability.
J Food Comp Anal 2015; 39: 111-119.

43. Somavilla M, Oliveira VR, Storck CR. Centesimal and mineral composition in freezing and associated microwave use for thawing beans (Phaseolus vulgaris L.). Disciplin Scient 2011; 12; 103-114.

44. Porres JM, López-Jurado M, Aranda P, Urbano G. Effect of heat treatment and mineral and vitamin supplementation on the nutritive use of protein and calcium from lentils (Lens culinaris M.) in growing rats. Nutrition 2003; 19; 451-456.

45. Ranilla LG, Genovese MI, Lajolo FM. Effect of different cooking conditions on phenolic compounds and antioxidant capacity of some selected Brazilian bean (Phaseolus vulgaris L.) Cultivars. J Agric Food Chem 2009; 57: 5734-5742.

46. Silva MO, Brigide P, Toledo NMVD, Canniatti-Brazaca SG. Phenolic compounds and antioxidant activity of two bean cultivars (Phaseolus vulgaris L.) submitted to cooking. Braz J Food Technol 2018; 21: 1-8.

47. Sánchez MNA, Jiménez MC, Cardador MA, Martín CBS., Dávila OG. Physical, nutritional and non nutritional characterization of Inga paterno seeds. Rev Chil Nutr 2016; 43: 400-407. 